\title{
Schoolification or Early Years Democracy? A Cross Curricular Perspective from Denmark and England
}

\author{
Sigrid Brogaard-Clausen \\ Senior Lecturer in Early Childhood Studies \\ University of Roehampton \\ Roehampton Lane \\ London \\ SW15 5PJ \\ 02083925783 \\ s.brogaard-clausen@roehampton.ac.uk
}

Author bio: Sigrid Brogaard Clausen is a senior lecturer and researcher in Early Childhood at the University of Roehampton, United Kingdom. Her research interest arise from her experience of the Danish and the English early years and range from the policy conditions for children's well being, learning and democratic participation to the development of professional identity in 'early years'. She is currently working on a collaborative research study into the recently introduced baseline assessment in England, examining teacher's experiences of working with wellbeing and involvement in the context of the assessment. Further to this she is taking part in research into parents' and early years practitioners' perceptions of children's well being. She is a Senior Fellow of the Higher Education Academy, England, and a member of the steering group of the Early Childhood Studies Degree Network, England. Correspondence; s.brogaard-clausen@ roehampton.ac.uk.

\section{Keywords: Early Years Democracy, Schoolification, Early Years Policy and Curriculum, (Language) Assessment, International Comparison, (England \& Denmark) (quality assurance, neo-liberal accountability, children, parents, professionals position)}

\section{Abstract}

International comparisons strongly influence national policy agendas in early years. However, an appreciation of details and national context and differences are imperative to promote democracy. From the perspective of a Danish social pedagogue lecturing in Early Childhood Studies in England, the author presents a cross-national comparison to elicit parallels and differences in discourses of democracy and schoolification within early years curriculum policies in England and Denmark. An initial discussion of democracy and schoolification leads into a consideration of the differing welfare contexts and quality assurance processes that inform the curriculum frameworks. The influence of schoolification is exemplified in a detailed analysis of the raised expectations with regard to language assessment in England and Denmark. This discussion reveals the tensions between local democratic participation in early years communities and policy agendas that emphasise preparation for school. The article explores how limitations of a schoolification discourse, already dominant in England and becoming more prevalent in Denmark, potentially dis- 
positions children, parents and professionals as democratic stakeholders. The conclusion takes the form of an invitation to the early years community, locally, nationally and internationally to find ways of developing resilience to the pressure of neo-liberal accountability culture and external governance.

\section{Introduction - cross national comparisons and concern for early years democracy}

International comparisons of early years inform both research and policy, but can be used to promote ideology without an appreciation of the differences of national detail and context (see for example More Great Childcare, DfE, 2013 and the Henehan and Cooke critique, 2012). These comparisons become part of a global discourse which is dominated by market forces, governance and government (Blommaert and Bulcaen 2000; Fairclough 1992,2003). Further reviews of early years policy discourses and developments are therefore required to enable us to know how these international comparisons affect early years, nationally and internationally.

This article aims to bridge a gap in knowledge of the different ways early years curricula are organized in England and Denmark (Winter-Lindquist 2013). From the perspective of a Danish pedagogue lecturing in Early Childhood Studies in England, the author presents a cross-national comparison to elicit parallels and differences in the discourse of democracy and schoolification within the policies. Early years democracy can be understood as children and adults taking part in communities of active participation, responsibility, emancipation and egalitarianism (Dahlberg, Moss \& Pence 2007). A democracy that is perceived as being threatened by a neo-liberal discourse of accountability and 'schoolification'; a term used when the early years are understood as pre-schooling and not achieving legitimacy on their own terms (Jensen et al, 2010, Klitmøller \& Sommer 2014).

The development of early years curricula is a national policy direction located within the context of a wider movement of harmonization in European education policy (Sahlberg 2012, Kampman 2013). As European early years policies converge, the contrast between a Nordic 'social pedagogical approach' and a French-English 'early education approach' or 'readiness for school tradition' has been identified (Organization for Economic Cooperation and Development, OECD 2006). Nevertheless the Nordic/Danish tradition of democracy in early care and education has often been promoted in England (Penn 1995; Davis 1998; Boddy et al, 2006; Moss 2007; 2010; Petrie et al 2009; Henehan and Cooke, 2012; Boffey \& Rock 2012). 
In evaluating changes to the Danish early years, examples of English early learning and the involvement of parents have also been presented as inspirational practice in Denmark (Olesen 2014). A question that arises from this is; how such international comparison and harmonization demotes or promotes national and local democracy?

The discussion in the article is based on an analysis of curriculum documents and research within the two countries and presents a summary of findings, drawing on key document samples to illustrate points. Informed by Fairclough's (1992, 2003) critical discourse analysis and Bang \& Door $(1995,1998,2000)$ eco-linguistic theory, the governmental policies are interpreted as representations of social production and reproduction of power and ideology. To illustrate this examples are presented on how the language used in the curricula, contributes to the constitution, reproduction and change of social subjects, -relations and situations. While comparing and contrasting key discourses and developments in early years curricula, the author reveals similarities and differences on the positioning of parents, professionals and children (Moreau 2011, 2014).

The presented research is based on the view that a transparent dialogue and knowledge development in research, policy and practice, both nationally and internationally, is imperative in a democratic society (Henehan and Cooke 2012; Urban 2012). From a perspective informed by comparative studies stakeholders can participate in practice and policy development within early years and thereby create local, national and international communities capable of working towards democracy in early years (Henry et al 1999). After a brief outline of the early years curriculum frameworks within the two nations, the article moves on to expand on the initial notion of early years democracy and schoolification. The article proceeds into an outline of national and local characteristics of early years schoolification and democracy in England and Denmark and highlights differences and similarities between the two nations. Considerations of the differing social welfare context and quality assurance processes are presented before moving on to an examination of the positioning of parents, practitioners and children within the early years curricula context. Finally the article will illustrate a schoolification discourse in the understanding of children's language assessment in England and Denmark and conclude in debating the movements in early years; democracy versus neo-liberalism. 
The next section provides an outline of the two curricula to preface the discussion of schoolification; the points raised here will be developed further below.

\section{A brief outline of the current picture: early years curricula in England and Denmark}

The Early Years Foundation Stage (EYFS) (Department for Education (DfE) 2014) is the current early years curriculum in England, encompassing birth to five-years, based in a tradition of early years curricula since 1996. At two years children's developmental/learning progress is assessed (DfE 2012a) and the Early Learning Goals (ELG) forms a statutory end of curriculum assessment of 5-year-olds. Compulsory schooling begins from the term after a child's fifth birthday, but children generally begin school in what is known as 'reception class' in the year that they turn five, some only a few weeks after their fourth birthday. The statutory curriculum therefore overlaps both the early years and the beginning of primary school. Although the EYFS is still statutory and is proposed to remain so, concerns raised with regard to children's academic attainment have led the government to introduce a baseline assessment of children upon entry to reception. This will replace the ELG from 2016. The aim of the baseline assessment is to provide numerical scores on children's attainment that will be linked into school accountability (Brogaard Clausen et al 2015).

In comparison to the English curriculum, the Danish early years curriculum functions as a set of broad-based regulations, as it does not detail method or provide specified framework for individual assessment of children unlike the more prescriptive English curriculum. The Danish early years curriculum, The Pedagogical Learning Plan, was introduced in 2004 and includes five overall aims and the six learning themes (Ministery for Social Affairs (MfSA) 2004). From 2004-2014, the aims have been adjusted in 2007 and 2010, however the learning themes and the stipulation that each individual setting should develop a learning plan remains: Each setting has to incorporate the overall aims and learning themes set in the law, and produce a plan for 6-months to 2.5-years-olds and a plan for 3-years-olds to school aged children. Children begin school in what is known as 'kindergarten-class' in the autumn term after they turn six. In light of international harmonization, it is important to draw attention to the requirement of a language assessment of all 3-year-olds that was introduced in 2007 and for 6-year-olds in kindergarten-classes in 2009, this was followed by kindergarten-class becoming compulsory in 2011. 


\section{Early Years Democracy and Schoolification - conceptual examination}

The idea of early years democracy has gained strength since the ratification of the United Nations Convention on the Rights of the Child (United Nations 1989) and was promoted by the OECD 'Starting Strong' in 2006. The individual's personal and professional identity and authority is essential in creating the democratic environment (Pramling-Sammuelson 2004). This democratic environment provides space for public voice and (visible) identity formation as children and adults are given opportunities to develop responsibility and take part within a range of democratic communities and influence decisions. Consequently democracy becomes both content and method. However as Grindheim (2014) reminds us 'democracy is not a settled system or a defined way of governing a community' (p. 310). It is both changeable and changing. Democracy is an ideal, a way of life where we strive for equality, emancipation and a good life, and where compromise and solidarity is essential as we bring in different interests and conflicting perspectives. As Cohen (1970) originally argued the democratic ideal is the position from which we should challenge regulations that limit the opportunities of participation in decision making.

As the importance of early childhood becomes recognized, governments are investing in the education of the very young children. With this investment comes policy development, which has brought what Jensen (2005) calls 'the discourse of manuals' into the day care and teaching professions, forming part of the assumption that such manuals will ensure appropriate foundation for a future workforce. As governments seek to invest in the development of knowledge capital, comparison and competition in the educational discourse are promoted (Pirard 2011; Penn 2011; Lloyd and Hallet 2010; Sahlberg 2012; CampbellBarr \& Nygaard 2014). Following this trend arguments for international comparison of onschool-entry assessments have been made (Tymms et al 2014). However, the OECD have identified 'learning to be', 'learning to learn' and 'learning to live together' as important goals for young children, warning that narrow discourses about readiness for school may restrict some of the opportunities children have to reach these goals (OECD 2006, p 219). In line this the United Nations Educational, Scientific and Cultural Organization (UNESCO 2010) warns how such schoolification presents an 'enhanced risk' due to the pressure put on early years 'as a preparation place for school'; schools that are often perceived as conservative institutions not open to dialogue with the early years community (p 119). This schoolification pressure on early years communities and the promotion of individual 
competitive assessment is suggested to create an accountability culture where performance pressure threaten democratic values in early years (Dahlberg et al, 2007; Moss, 2007, 2010, 2013; Petrie et al, 2009; Rose \& Rogers 2012; Kampman 2013; BERA/TACTYC 2014; Klitmøller \& Sommer 2014).

\section{Schoolification and neo-liberalism and the English early years curriculum}

In a historical review Brehony and Nawrotzki (2011) established how the English centrally set curriculum was based in a positivistic approach with the neo-liberal aim of creating a future workforce. The emphasis on schoolification was apparent in the introduction of centralized and prescribed learning outcomes in the 'Desirable outcomes for Children's learning on Entering Compulsory Education' (DfE/ SCAA, 1996). With the introduction of the Early Years Foundation Stage in 2000 (DfE \& Qualifications and Curriculum Authority (QCA 2000) children's play, interests and learning opportunities were emphasized rather than particular outcomes or goals. A formalized system of assessment of Early Learning Goals was nevertheless introduced in 2002 to measure the individual child by the end of reception, in a 'pre-school' assessment (DfE \& QCA 2002). The assessment was based on prescriptive normative sequential and predetermined outcomes, which Solar and Miller (2003) critiqued as an instrumentalist approach that was economically driven; restraining, anti-egalitarian and anti-democratic. This discourse arguably promotes a neo-liberal ideology of individual competition in a knowledge economy (Esping Andersen 1990, et al 2003). A reviewed curriculum in 2007 reiterated a holistic, play focused and less prescriptive curriculum, however the teachers were still required to produce individual profiling of each five-yearold's attainment, assessed in relation to the 69 ELG descriptors (Department for Education and Skills (DfES) 2007). Following a change in government, the new coalition government commissioned a review of the curriculum (Tickell 2011). This review led to a slimming down of the curriculum, citing practitioners' concerns over a too time consuming, complex and burdensome curriculum. With a decrease from 69 to 17 ELG, the changes were assumed to enable a better transition from the early years to the National Curriculum (DfE \& Department for Health (DfH) 2011a).

The English early years curriculum stresses the importance of equal opportunities, participation and an enabling environment so 'that every child makes good progress and no child gets left behind' (DfE 2012, p.2). Normalizing structure and goals are therefore 
introduced presupposing they will ensure later educational and economical achievement (Boddy et al, 2006). However Simpson (2010) and Basford \& Bath (2014) argue how this has meant increased accountability and performance pressure on the early years in England. This accountability culture contradicts evidence that show how increased and specific targets have little effect on achievement and learning and promotes surface learning (Amrein \& Berliner 2003; Nichols \& Berliner 2007; Klitmøller \& Sommer 2014). Blenkin and Whitehead (1988) and the OECD (2006) warn how a narrow curriculum, where content is organized into neat, logical programmes of instruction, removes the control of the learning process from the child. As Moss stresses the focus on achieving narrow normative targets gives 'no democratic space and gives no encouragement to democratic practice' (2007, p. 10). Alexander's (2010) review confirmed how such targets apply pressure on children to 'perform academically' at too early an age. This pressure is not limited to the children, but consequently also affects professionals [and parents] who have to prepare young children for school by 'writing more', which establishes 'a top down' pressure (Rose \& Rogers, 2012). Dahlberg, Moss and Pence (2007) projected how curricula can be a way to introduce structures for comparison and assessment of performance and for governing at a distance, and in so doing potentially hindering local democracy and emancipation. These concerns are shared by House (2012), who outlines how the schoolification of early years in England presents a reductionist understanding of the complexity of young children's present and future lives. The Professional Association for Childcare and Early Years research into school readiness similarly reflects early years professionals' concerns over a 'schoolification' of early years (PACEY 2013). This concern is hard to refute, as the curriculum specifies the aim of promoting 'teaching and learning to ensure children's 'school readiness', assessed against centrally set goals (DfE 2012, p 2).

\section{Danish Early Years Democracy and the Danish early years curriculum}

International research places Danish children, parents and professionals as competent citizens that take part in a Democracy. They contribute with their varied experiences, points of view, interpretations and ideas within a community (Brostrom \& Wagner 2003; Einarsdottir, \& Wagner 2006; Petrie et all 2009; Moss 2010). Children's self-governed activity and a personal, reflective and relational pedagogy are key values that underpin Danish early years. Juul Jensen (2011) and Ringmose \& Krag-Muller (2013) portray how Danish pedagogues 
and children do not exist in separate hierarchical domains but in shared life spaces. The promotion of child-child relationships and interactions, places the 'horizontal relationships' as equally important as the 'vertical relationship' to the adult (Broström \& Frøkjær 2012). Nonetheless, as discussed above, the democratic focus on equality and emancipation entail an ongoing negotiation of 'who knows best' and 'who makes the decision'. This has led to research pointing to how the professionals do not always recognize their own importance sufficiently (Ringmose \& Krag-Muller 2013), and therefore do not take enough lead in the children's learning (Broström \& Frøkjær 2012). Koch (2012) proposes how the ideal of a happy and harmonious child embeds itself in the Danish democratic early years, which potentially causes exclusion for the child that does not fit in to this ideal. Similar concerns about exclusion are shared by pedagogues, where a poor staff-child ratio was observed to hindered inclusive pedagogy (Denmark's Evaluation Institute (EVA) 2014). These concerns remind us that the ideal of democracy is a daily challenge to ensure inclusion, equality and emancipation.

The Danish tradition of emancipation, autonomy and self-governance meant that there was resistance to the external political interference, structure and control when the Pedagogical Learning Plans (MfSA 2004) were introduced in Denmark in 2004. The implementation of the learning plans increased the concern of a 'schoolification' of day-care, where bringing in more school preparatory structured learning in early years institutions was perceived by some as hindering a 'good life' for children (Clausen 2005; Jensen 2009; Jensen et al, 2010; EVA 2012; Krag-Muller 2014). The plans were interpreted as a part of an accountability culture and there was strong opposition to centralization and standardization and the implicit lack of trust in local democracy (Socialudvalget 2004). The Danish curricula did not however imply structured school preparatory activities nor did it initially provide any centrally set assessment expectations.

A 2008 evaluation pointed to a significant $93 \%$ of pedagogues that found that the learning plans had made a positive impact on professional identity and quality (NIRAS 2008). Despite this, $50 \%$ of the managers deemed that they were too time consuming and took the manager and the pedagogues away from being with the children, reiterating how 'the discourse of manuals' creates a pressure on the professionals and children. In 2012 setting leaders reported that the plans had become less of a burden; however expectations and 
support in the different municipalities varied significantly (EVA 2012). Already existing concerns with too high child/adult ratio and an increased administrative burden reducing the time spent with the children have been reiterated (Glavind \& Pade 2014). Poor ratios limits children's time and opportunity for individual/small group activities with an adult (KragMuller 2014). Managing the curriculum decreases the adults' time spent with the children in both Denmark and England thereby affecting the quality of provision. The context of the early years provision also needs to be considered in light of the differing welfare state models within the two countries, influencing access to provision and quality assurance of settings as essential parts of early years democracy.

\section{The differing welfare state contexts}

To understand the prevalence of schoolification in England, the distinction between the Danish social democratic and an English neo-liberal welfare state models needs to be explained (Esping-Andersen, 1990, et al 2003). The Danish state guarantees and provides highly subsidized state childcare. In Denmark universal day-care is available for all children and subsequently $91.2 \%$ of one to two year olds, and $97.2 \%$ of three to five-year-old children access full time state-day-care. A maximum of $25 \%$ of cost is to be paid by the parents and less than 5\% of nurseries are privately run (Denmark's Statistics 2011, 2014; Pedersen 2011).

In contrast the English state depends on a large private childcare sector and high parental contribution for childcare. The economic drive and market approach is predominant in England (Campell-Barr \& Nygaard 2014) and evident in the Childcare Act 2006, where it was specified that state or local authority childcare provision may only be provided as a last resort (Department for Education and Schools (DfES) 2006). Although having a compulsory school start at age five, free schooling for four year olds means that a majority of children commence (fulltime) school when they are four years old (98\% benefit from 'free early education'). By comparison, the funding for 3-year-olds is limited to fifteen hours per week, where $93 \%$ benefit from 'free early education'. Further to this, since 2013, fifteen hours have been offered to two-year-olds who are designated as disadvantaged (DfE 2011, DfE 2013). However provision outside these age groups and outside the funded 15 hours is at a high cost for parents (Lloyd \& Hallet 2011). State funding and/or privatization indicate discourses of governance (Fairclough 1992, 2003). In examining how governmental policies represent and reproduce power and ideology, the systems of quality assurance and governance become highly significant. 


\section{Quality Assurance in Early Years in England and Denmark}

Quality assurance, power and control in the English early years curriculum is located within an educational administration, with centrally set goals and published inspection reports and comparisons. The Office for Standards in Education, Children's Services and Skills (Ofsted) has the responsibility of ensuring quality in early years settings and schools. This administrative authority is well established, with a tradition of external inspection visits based on centralized standards and goals that have been critiqued for having little supportive focus and a lack of knowledge of the specific settings and its children (Baldock 2001; Soler \& Miller 2003; Sahlberg 2012). As an overview by the Office for Standards in 2011 revealed; the 'inspection's role in improvement is not clear (...) and [is] leading to inconsistent experiences and expectations of inspection' (DfE \& DfH 2011a, p. 5).

In Denmark there have been a number of changes to quality assurance in recent years. With the implementation of learning plans, quality assurance was shared between a parent board that governs each setting, and the local municipality (MfSA 2004). The municipality had the responsibility for developing an overall children's plan, setting goals for the local area, visiting individual settings and taking the role of a 'critical friend'. The quality assurance process consisted predominantly of these visits and an evaluation of the setting's documentation (NIRAS 2008). As the evaluations often consisted of contextualized narratives from pedagogical practice it was perceived as difficult, to set overall (decontextualized) goals (EVA 2009), which meant that municipalities and their consultants struggled to keep an overview (EVA 2012). In 2008 the EVA was given a national responsibility for 'systematic collection, analysis and dissemination of knowledge' as well as evaluating the daycare 'area' (Ministry for Children, Equality, Integration and Social Affairs (MfCEISA) 2014; § 18). This could evidence a part of an international trend of external quality assurance and comparison (Henry et al 1999; Sahlberg 2012; Kampman 2013). In contrast to the English Ofsted, these evaluations were not assessments of individual settings, however a promotion of systematic planning and documentation was evident in the EVA evaluation in 2012 (EVA 2012). This could indicate an external accountability pressure requiring specified methods of planning and documentation. The external quality assurance and curricular discourses described above also led to a re-positioning of parents, professionals and children in both countries. 


\section{The (re-)positioning of parents, professionals and children in the early years curricula context.}

The position(ing) of parents

One of the main aims of the learning plans in Denmark was to make early years practice more visible to parents and provide them with a strong voice (MfSA 2004). As the policy set general regulations rather than a prescriptive curriculum, the parent boards had a key role in approving and evaluating a setting's individual plan. Parents felt they received more information following the introduction of the plans, although they requested further documentation, they also expressed trust in the professionals (NIRAS 2008). The professionals perceived the parental communication to have been improved in an EVA (2012) survey of a sample of settings, however no parents were directly consulted and parental involvement and control were perceived as questionable in a later study on inclusion in 2014 (EVA 2014). In addition, in 2007, a change in the Danish law had designated more responsibility and power to the leader of the setting, who was now responsible for the plan, rather than the parenting board (Ministry for Families (MfF) 2007).

Moss' (2012) research establishes how English parents have increasingly been positioned as consumers rather than participants in an early years democracy. The Ofsted review (DfE \& DfH 2011a) recommended that more parents were to be involved in the inspection process, but Government perceived this to be a matter for the Ofsted Chief Inspector to decide upon (DfE \& DfH 2011b). The Tickell review (2011) further emphasized the need to create more time for the involvement of parents. However, the latter reads more as a need for educating parents; 'encouraging more mothers and fathers to become involved in their child's development, helping them understand how to enable their children to make good progress' (ibid, p. 99). As well as positioning parents as consumers, this discourse reiterates findings from research that positions parents as being in need of education or needing to know what effective parenting means, which is also present in the EYFS itself (Butcher \& Andrews 2009, Cottle \& Alexander 2013; DfE 2014). In comparison, the position of the Danish parent is more locally governed.

The position(ing) of the workforce

A range of research has established how government policies impact on professional identity and position, where prescriptive curricula reduce professional autonomy (Osgood 2006;

Miller 2008; Lloyd \& Hallet 2010; Moss 2010; Bradbury 2012). As Bradbury (2012) 
exemplifies, the introduction of the English early years curriculum made the professionals feel incompetent, unsure and under pressure. According to Pirard (2011) it is necessary to strengthen early years professionalization alongside the introduction of curricula in order to ensure quality development and to reduce standardization. The workforce in early years in Denmark and England differs significantly in level of qualification and education. In Denmark $60 \%$ of workers in early years settings are degree qualified whereas in England the Nutbrown review identified low training and a complexity of different national vocational qualifications (more than 200) with only $8 \%$ of the workforce holding a degree (Nutbrown 2012; Henehan and Cooke 2012). Contrary to the Danish workforce, the English early years workforce has no professional accreditation, nationally set or regulated pay-scale or employment conditions (Lloyd \& Hallet 2010).

The education of the early years workforce influences whether professionals see themselves as interpreters or implementers of curricular frameworks and goals (Oberheumer 2005). English early years practitioners' confidence and freedom to interpret the curriculum is a struggle that is identified in Cottle and Alexander's (2012) research. In combination with the external inspection system this has the potential to dis-empower professionals and consequently hinder early years democracy and emancipation (Moss 2013). The limitation of power and emancipation of the English early years workforce continues to promote conditions for a 'technical expert' with limited opportunities for exercising professional values and understandings in practice and policy development (Osgood 2006; Oberheumer \& Scheryer's 2008; Moss 2010). The focus on prescribed routes and assessed standards skew practitioners' ability to observe children in an open-ended manner (Daniels 2012), as Basford and Bath $(2014 ; 120)$ propose this can make it 'difficult to recognize children as individual and potentially idiosyncratic learners.'

In Denmark the education of pedagogues has similarly been going through several changes within the last decade. With an emphasis on academic skill, goals and output the pedagogue are being positioned in an 'accountability and schoolification discourse' (Tuft 2012; Momsen 2012; Rothuizen \&Togsverd 2013; Brogaard Clausen 2015). Based in the above research this potentially erodes the Danish early years workforce tradition of 'democratic professionalism' with reciprocal relationships with colleagues, children and parents (Oberheumer \& Scheryer's 2008). A ‘lighter’ Danish curriculum would be considered an example of emphasizing the importance of highly skilled practitioners (Bertram and Pascal 
2002:38). However, in addition to being placed within an accountability and schoolification discourse, the municipality now decides on voting rights of the early years professional represented on the 'parent board' and this, together with the strengthened position of the leaders, introduces a hierarchical structure that may potentially dis-empower the professional (MFCEISA 2014).

\section{The position(ing) of the child}

Danish Law stipulated that the setting's plan has to be based in the (specific) composition of children within the setting (MfSA 2004, paragraph 8) and that children's play, spontaneous initiatives and exploration are not to be compromised by planning (MfSA 2004). Early years democracy was reiterated with the aim to include; 'children's participation in decision making' and 'co-responsibility' and an 'understanding of democracy' (SM 2004, paragraph 8a). This points to a 'social pedagogical approach'; more local, child-centered and holistic'(OECD 2006; Jensen et al 2010). In comparison the English curriculum's overarching principle of 'children learn to be strong and independent through positive relationships' (DfE 2012; p. 3) indicates an emphasis on the individual's achievements - the individual gain through positive relationships. In contrast to the Danish social pedagogical discourse, this evidence an English 'readiness for school tradition', with more centralized academic aims and method for the individual child to be assessed in (OECD 2006; Jensen et al 2010).

External control and hierarchical structure is evident in the English approach to the individually assessed child, and the comparative assessment suggests a positivistic tradition of evaluating visible and measurable outcomes in a competition discourse (Brehony 2000; Bradbury 2012). In the Danish curriculum the children were positioned to take part in planning as democratic participants and a ministerial publication of the learning plan clarified that the 'documenting is not about evaluating each child's learning within the six themes (Ministry for Social Affairs (MfSA) 2005, p. 7).

\section{Schoolification exemplified}

The schoolification of early years was reinforced in England by the raised expectations for children's literacy in the early years curriculum in 2012 (DfE 2012 (these aspects have remained the same in the 2014 version)). Instead of seeking an early beginning of literacy as 
in the 2007 version (DfES 2007) the expectation in 2012 was for 5-year-old children to display literacy, and the discourse shifted to a technical vocabulary. Children were now being assessed according to their ability to; 'read and understand simple sentences' and 'use phonic knowledge to decode regular words' and 'read them aloud accurately' (2012) in comparison to (2007) where children were to; 'read a range of familiar and common words and simple sentences independently and read books of own choice with some fluency and accuracy'. In these goals the child is moved from being 'an engaged learner'; evidenced in wording such as; 'own choice', 'developing a familiarity', ' making (plausible) attempts at', ' beginning to', 'express some' and 'sometimes using' to a 'technical performer' under strengthened instrumental language of 'performance': to display, use and match (2012).

Children's language and literacy acquisition became a technical performance; 'the interest in stories, the use of language to imaging and to recreate roles and showing awareness of the listener' (2007), all representing creative, (playful) social and emotional aspects of language and literacy, were taken out of the assessment framework in 2012. In the Learning Goals (2012) words like creativity, imagination, joy and questioning have been replaced with the instructional discourse of 'answering appropriately', 'follow instructions', 'express themselves accurately and effectively' and to 'answer questions' (DfE 2012) - rather than to ask them. This promotes a hierarchical discourse that dis-empowers both child and adult. Measurable achievements are given value over less measurable outcomes such as social and emotional well-being. The fundamental aspect of language and literacy as an emotional and social communication to and from others is therefore devalued. With a prescriptive, normative, sequential and instrumental approach to young children's holistic learning, the policy represents a very restricted (and restricting) understanding of children's learning where only the measurable is deemed valuable. Baldock et al. (2013) similarly found that the school-readiness agenda has been strengthened, with the new learning goals aligning more closely with the National curriculum. Despite a movement towards assessment for learning in the first decade of the century (Basford \& Bath 2014), the curriculum and the recent introduction of a baseline assessment on entry to reception, reinforces the assessment of learning (Brogaard Clausen et al 2015). Such excessively formal curriculum in early years could discourage children from learning (Sylva \& Pugh 2005). Alexander (2010) explains how children in England, despite having comparatively high reading scores, often lose pleasure in reading. As Anning already argued in 2005; 'if the curriculum was genuinely 
designed around children's learning needs, perhaps then we would encourage a generation of children with a love of learning rather than groups of anxious and dispirited 'beginning readers' already feeling that they are failing' (p. 26).

In comparison to the English the Danish curriculum only provides minimum specification on expectation of language awareness. Placed in an 'appendix' the government guidance remains limited to: Language (vocabulary, pronunciation, knowledge of the written language, rhymes and proverbs, the existence of numbers, letters and what they are used for, IT/Media and communication) (MfSA 2004/MfF 2007/ Ministry for Social Affairs and Welfare (MfSAW) 2010). It is then the specific setting that decides methods and emphasis on the different parts. The 'Gold Guide' (MfFCA 2005) that was published by the Ministry, expressed no intention of introducing (formal) reading and writing in early years. However from 2007, language assessment of all 3-year-olds became compulsory (MfF 2007). Assessment results were to be reported to the local municipality and could be used to evaluate and publish quality of practice in settings and further structure the municipal aims and framework (Kommunernes Landsforening et al 2010). At the same time, changes in the education of the pedagogues strengthened Danish as a subject in 2007, and language assessments for all children on entry to kindergarten became compulsory in 2009, indicating more subject specific focus in line with other European early years movements (Oberheumer 2005; Boddy et al 2006; Sahlberg 2012). However in 2010, the law replaced the language assessment of all 3-year-old with targeted assessment and compulsory intervention (MFCEISA 2014: MfSAW 2010, still the existing law in 2014). Nevertheless the recommendation remains to assess or at least screen all children, and in 2012, $85 \%$ of settings used the government developed test (Servicestyrelsen 2012). When specific skills are singled out and assessed for school readiness, particularly in a test format, it indicates a schoolification of early years (Bauman 2011; Klitmøller \& Sommer 2014; Tonsberg 2014). Emerging evidence reveals how the curriculum has led to pedagogues focusing on accessing children's knowledge and thereby interrupting their play and creating a hierarchical relationship (Hviid 2011). Researchers in Denmark continue to express concerns about the neo-liberal schoolification, and report that test culture leads to performance anxiety which takes away the child's desire for learning, curiosity and self-esteem (Klitmoller \& Sommer 2014). This leads Schultz Jorgensen to conclude that 'children have almost no value in 
themselves any more' (Schultz Jorgensen cited in Krog-Sorensen 2014) reiterating the tension between democracy and schoolification in early years.

As Pramling-Samuelson identifies all curricula are value-orientated, either explicitly or implicitly (2006), and the above analysis shows how curricula discourse is 'socially constitutive as well as socially conditioned' (Blommaert \& Bulcaen 2000). Explicit and centralized goals for the children constitutes an English society focused on learning outcomes, conditioned by a schoolification discourse. The Danish curriculum's structures of dominance, normativity, discrimination, power and control in language (Fairclough 1992, 2003), appear in a more implicit way as aims and goals are locally set. Local governance has been further strengthened by law changes in 2010 and the policy maintains a strong notion of democracy, however evaluation practices and language tests imply a move towards more schoolification and external power and control.

\section{A neo-liberal pressure on early years Democracy}

Kampman (2013) identifies an international political drive towards early education and individualization in a competition society. In 2004 it was stipulated that the learning plans had to be based in the (specific) composition of children within the individual setting (MfSA paragraph $8 \mathrm{a}$ ), and the children's play, spontaneous initiatives and exploration were not to be compromised. In the 2007 law, the position of children as democratic citizens was nevertheless weakened; 'On preparation of the pedagogical curriculum, the composition of the group of children shall be taken into consideration' (MfF 2007) The setting's children were moved from being the starting point in 2004 to 'just' being taken into consideration which was concurrent with the strengthening of the leader position within the curriculum agenda and indicated a more hierarchical structure. It is, however, more complex than a simple move towards schoolification, as since 2007, the curriculum law made it compulsory to work with 'a child perspective' within the new 'environmental law', making interviewing children a perceived requirement (Dansk Center for Undervisningsmiljø 2014) . $^{\mathrm{i}}$

With more external governance and control, the question is how much room is there left for recognising and negotiating differing opinions, values (Grindheim 2014). In the national evaluations of the learning plans (aspects), there has been no consultation with parents or children, and very little with the pedagogues (EVA 2012, 2014). In evaluating whether the 
plans have made an impact on children's learning, judgments were predominant from kindergarten-class teachers and local municipality consultants (EVA 2012). Interviews with 15 setting leaders were included, but it is striking that there were no references to children's involvement in developing the learning (plans), despite such involvement being stipulated in the departmental order. A tension has arisen between the democratic principles set in the law and the lack of the children's voice in the civic and public sphere of participation (ArlemalmHagser \& Davis 2014). A move towards a more hierarchical structure restricts opportunity to influence decisions, challenge regulations and external assessment, which limits the professionals, parents and children's opportunity to influence. The National Evaluation Instityte, EVA (2009) has developed guidance for learning and quality evaluation, but also assesses the implementation of these (EVA 2012), which points towards a centralization of power external to the settings, potentially resulting in external demands of change to practice in the early years settings (ibid p. 65). This hinders emancipation and conflicts with the OECD recommendations for involvement of local stakeholders, and demotes 'local initiative and experimentation' (OECD 2006: 221).

\section{Final considerations and conclusion}

In an era of international comparison and performance competition, it is increasingly necessary to identify how raised targets of normative and prescriptive goals put pressure on young children, parents and professionals. Governments understand the need and importance of investing in early years, however this then comes at the cost of becoming more scrutinized, accountable and controlled (Oberheumer 2005). This is problematic since the 'soft values' are less measurable' and therefore curricula assessments are likely to be driven by assessing and comparing the measurable, such as in language assessments and tests. Lenz-Taguchi (2010) points out, that the more we know about the complexities involved in young children's learning and meaning making, the more tendency there is to shape policy around narrow, controlling, complexity-reducing curriculum and teaching strategies.

The pressures of individual child profiling and external inspection hinder English children's freedom and democratic participation, promoting individualism, 'technical performance' and restricting the understanding of children's learning. At the same time it demotes professionals' 'philosophies, values, morals and ethics of care' (Cottle and Alexander 2012) and only appears to include parents as 'in need of learning' and/or consumers, rather than as 
equal citizens. The neo-liberal discourse hinders local democracy; parent, professional and children's voices.

Danish early years is well rooted in a social welfare state model and a social pedagogical practice. However a neo-liberal schoolification discourse is becoming evident in increased expectations of individual testing, external evaluations and accountability. This suggests that Denmark is moving from a welfare state to a competition state, where, rather than protecting citizens from the international competition pressure, it is led by it (Pedersen 2011a). Despite language assessment no longer being compulsory, language tests have now become predominant practice. The local municipal leadership to a large degree sets the agenda for early years in Denmark. Heavily influenced by international comparisons, central evaluations and initiatives the municipalities though appear to be leading towards schoolification of early years. Consequently the traditional egalitarian and democratic culture in Denmark becomes increasingly hierarchical and dictated by externally set strategies dis-positioning democratic participation of children, professionals and parents. As Dencik (1989) warned two and a half decades ago, we appear to continue an instrumental cost-benefit agenda, where the neoliberal approach to investment and return overrules the children as agents and citizens and there is a failure to recognize childhood from the intrinsic value to the child itself.

The question therefore remains; are professionals, parents and children able to establish and maintain equality and democracy in early years' settings under pressure from a neo-liberal cost-benefit agenda? Can we by strong advocacy in early years promote the democratic values, develop resilience to the pressure of a neo-liberal accountability culture and external governance? The Danish policy still maintains strong features of democracy and voice and emphasising this lawful entitlement can aid in the resistance to pressure from neo-liberal accountability and testing culture. Ongoing research in England poses the question as to whether observation led baseline assessment, focusing on wellbeing and involvement would turn practitioners, parents and politicians' attention towards more human recognition and appreciation of the life the children live now? The research proposes how such assessments are equally, if not more relevant in supporting children in the preparation for school and future life, whilst maintaining a recognition of democracy, voice and wellbeing (Brogaard Clausen et al 2015). As researchers, parents, professionals and politicians we need to engage in local initiatives. We need to have local, national and international, active and informed citizens that resist being treated as objects or consumers in a neo-liberal cost-benefit agenda 
(Henry et al 1999). This is to ensure that we keep seeing the child, as an individual and within the context of their strong connection to friends, family, professionals and the community - and seeing childhood as having intrinsic value to the child itself and to the community and society as a whole.

\section{References}

Alexander, R.J. (ed.) (2010) Children, Their World, Their Education: Final Report and Recommendations of the Cambridge Primary Review. London: Routledge.

Amrein, A. T. \& Berliner, D. C. (2003) The effects of high-stakes testing on student motivation and learning. Educational Leadership, 60(5), 32.

Anning, A. (2005) 'Play and legislated curriculum. Back to basics: an alternative view' in Moyles, J., (ed.) (2005) The Excellence of Play, $2^{\text {nd }}$ edition, Maidenhead, Open University Press (first published: 1994)

Baldock, P. (2001) Regulating Early Years Services. London; David Fulton Publisher

Baldock, P., Fitzgerald, D. \& Kay, J. (2013) Understanding Early Years Policy, $3^{\text {rd }}$ edition, London: SAGE (first published: 2005)

Bang, J. \& Door, J. (1995, 1998, 2000) Eco-Linguistic Theory Series, Odense: Odense Universitetsforlag

Basford, J. \& Bath, C. (2014) Playing the assessment game: an English early childhood education perspective, Early Years: An International Research Journal, 34:2, 119-132

Bauman (2011) Forord i Leg og Laering I Fremtidens Dagstilbud, Kobenhavn, Born og Unge Forskning http://www.bupl.dk/iwfile/BALG-8HMCK5/\$file/Forskning11.pdf

BERA \& TACTYC (2014) Policy advice and future research agendas, A BERA Early Childhood Special Interest Group/TACTYC: Association for the Professional Development

Bertram, A.D.\& Pascal, C. ( 2002) International Review of Early Years Curriculum and Assessment funded by QCA. London: Qualifications and Curriculum Authority

Blenkin, G.M. \& Whitehead, M.R. (1988) Creating a context for development, in G.M Blenkin and A. V. Kelly (Eds) Early Childhood Education, A Developmental Curriculum. London: Paul Chapman

Blommaert J and C Bulcaen (2000) Critical Discourse Analysis Annu. Rev. Anthropol. 2000. 29:44766

Boddy, J., Cameron, C., Moss, P., Mooney, A., Petrie, P. \& Statham, J. (2006) Introducing Pedagogy into the Children's Workforce. Maidenhead: Open University Press.

Boffey, D. \& Rock, L. (2012) Labour looks to Denmark for childcare policy.

http://www.theguardian.com/politics/2012/feb/18/labour-childcare-pledge-working-women

Bradbury, A. (2012) "I feel absolutely incompetent": Professionalism, policy and early childhood teachers', Contemporary Issues in Early Childhood Education 13 (3), 635-68 
Brehony, K. J. (2000) Montessori, individual work and individuality in the elementary school classroom. History of Education, 29(2), 115-128.

Brehony, K. J. \& Nawrotzki, K. D. (2011) From Weak Social Democracy to Hybridized Neo liberalism: Early Childhood Education in Britain since 1945. In K. Hagemann, K. H. Jarausch \& Allemann-Ghionda C. (Eds.), Children, Family and State:Time Policies: Child Care and Primary Education in Post-War Europe (pp. 237-256). New York, Oxford Berghahn Books.

Brogaard Clausen, S. (forth coming, 2015) The professional identity, power and control of the Danish pedagogue in Kragh-Müller, G. \& Ringsmose, C. The Nordic Social Pedagogical Approach to Early Years Learning, London, Springer

Brogaard Clausen, S., Howe, S., Guimaraes, S. \& Cottle, M. (2015) Assessment of young children on entry to school: Informative, Formative or Performative? International Journal for CrossDisciplinary Subjects in Education (IJCDSE) Volume 6, Issue 1, March 2015 p. 2120-2125

Broström, S. \& Frøkjær, T. (2012) Paedagogers syn paa laerimg i bornehaven i Sverige og Danmark, VERA Tidsskrift for paedagoger. 2012, No. 59, 37-41.

Broström, S. \& Wagner, J.T. (ed.) (2003) Early Childhood Education in Five Nordic Countries Perspectives on the transition from Pre-school to School. Aarhus, Denmark: Systime, Academic.

Butcher, H. \& Andrews, J. (2009) How well am I doing on my outcomes? In Eke, R., Butcher, H. \& Lee, M (eds) (2009) Whose childhood is it? The roles of Children, Adult and Policy Makers, London: Continuum

Campbell-Barr, V. \& Nygaard, M. (2014) Losing sight of the child? Human capital theory and its role for Early Childhood Education and Care policies in Finland and England since the mid-1990 Contemporary Issues in Early Childhood Vol 15 No 4 2014, p 346-359

Clausen, P. (2005) Børneliv og lareplaner. Academia, Aarhus

Cohen, C. (1970) Democracy. Athens:University of Georgia Press;

Cottle, M., and E. Alexander (2012) Quality in Early Years Settings: Government, Research and Practitioners' Perspectives. British Educational Research Journal 38 (4): 635-654.

Cottle M., \& Alexander E. (2013) Parent partnership and 'quality' early years services: practitioners' perspectives, European Early Childhood Education Research Journal, http://dx.doi.org/10.1080/1350293X.2013.788314

Dahlberg, G., Moss, P. \& Pence, A. (2007) Beyond quality in early childhood education and care: languages of evaluation, Vol. 2. New York: Routledge.

Danmark's Statistics/Danmarks Statestik (2011) NYT FRA DANMARKS STATISTIK Nr. 80 22. februar 2011 Børnepasning mv. 2010 Sociale forhold, sundhed og retsvæsen http://www.dst.dk/pukora/epub/Nyt/2011/NR080.pdf

Danmark's Statistics/Danmarks Statestik (2014) NYT FRA DANMARKS STATISTIK Nr. 146 20. marts 2014 Børnepasning mv. 2013 Flere born bliver passet ude. http://www.dst.dk/pukora/epub/Nyt/2014/NR146.pdf 
Dansk Center for Undervisningsmiljø, DCUM (2014) Borneinterview

http://dcum.dk/boernemiljoe/boerneinterview

Daniels, K. (2012) Supporting the Development of Positive Dispositions and Learner Identities:An Action Research Study into the Impact and Potential of Developing Photographic Learning Stories in the Early Years. Education 3-13: International Journal of Primary, Elementary and Early Years Education 41 (3): 300-315.

Davis, T. (ed.) (1998) Researching Early Childhood Education - European Perspectives. London: Sage.

Dencik, L (1989) Growing up in the Post-Modern Age: On the Child's situation in the Modern Family, and on the Position of the Family in the Modern Welfare State. Acta Sociologica 1989 (32), 2:155-180.

Department for Education (DfE, 2012) The Early Years Foundation Stage (EYFS), London: DfE.

Department for Education (DfE, 2014) The Early Years Foundation Stage (EYFS), London: DfE.

Department for Education (DfE 2012a) Early learning and childcare: guidance for providers and Improving the quality and range of education and childcare from birth to 5 years London: DfE. https://www.gov.uk/government/uploads/system/uploads/attachment_data/file/175311/EYFS__know_how_materials.pdf

Department for Education (DfE) (2013) More great childcare: Raising quality and giving parents more choice, London: DfE.

Department for Education (DfE) DfE \& Department for Health (DfH) (2011a) Education Committee Second Report. The role and performance of Ofsted, London: DfE \& DfH .

Department for Education (DfE) \& Department for Health (DfH) (2011b) Government response The role and performance of Ofsted: Responses from the Government and Ofsted to the Second Report of the Committee, Session 2010-12 - Education Committee, London: DfE \& DfH.

Department for Education (DfE) \& School Curriculum and Assessment Authority (SCAA) (1996) Desirable outcomes for Children's learning on Entering Compulsory Education, London: DfE/ SCAA

Department for Education DfE \& Qualifications and Curriculum Authority (QCA) (2000) The Curriculum Guidance for the Foundation Stage, London: DfE/ QCA.

Department for Education DfE \&Qualifications and Curriculum Authority (QCA) (2002) The Curriculum Guidance for the Foundation Stage - Early Learning Goals, London: DfE/ QCA

Department for Education and Schools (DfES) (2006) Childcare Act, London: DfES

Department for Education and Skills (DfES) (2007) Early Years Foundation Stage, London: DfES

Department for Education and Skills (DfES) (2011) Education Bill Early intervention Grant and free early education places for disadvantaged two-year-olds, London: DfES

Einarsdottir, J. and Wagner, J.T. (eds) (2006) Nordic Childhoods and Early Years Education: Philosophy, Research, Policy and Practice in Denmark, Finland, Iceland, Norway and Sweden. USA: Information Age Publishing.

Ellegaard, T. \& Stanek, A. H. (2004) Lareplaner i børnehaven: baggrund og perspektiver. Roskilde : Roskilde Universitetsforlag, Frederiksberg 
Esping-Andersen, G. (1990) The Three Worlds of Welfare Capitalism. Cambridge: Polity Press \& Princeton: Princeton University Press, 1990.

Esping-Andersen G., Gallie, D., Hemerijck, A. \& J Myles (2003) Why We Need a New Welfare State. Oxford; Oxford University Press.

EVA, Danmarks Evalueringsinstitut (2009) Evalueringer af padagogiske lareplaner $i$ kommunalt perspektiv. Copenhagen: Danmarks Evalueringsinstitut.

EVA, Danmarks Evalueringsinstitute (2012) Laereplaner i praksis. Daginstitutionernes arbejde med paedagogiske laereplaner: Copenhagen: Danmarks Evalueringsinstitut

EVA, Danmarks Evalueringsinstitute (2014) Inklusion i dagtilbud. Kortlagning af arbejdet med inklusion i daginstitutioner og dagpleje: Copenhagen: Danmarks Evalueringsinstitut

Fairclough, N. (1992) Discourse and Social Change. Cambridge: Policy Press.

Fairclough, N. (2003) Analyzing Discourse and Text: Textual Analysis for Social Research. London: Routledge.

Glavind, N. \& Pade, S. (2014) Notat om udviklingen i daginstitutionernes bemanding siden 1986 Copenhagen/Vaerlose Bureau 2000 - Analyse og forskning http://www.bureau2000.dk/images/udgivelser/Born_og_unge/Normeringsudvikling\%20siden\%20198 6.pdf

Grindheim, L.T. (2014) 'I Am Not Angry in the Kindergarten!' Interruptive Anger as Democratic Participation in Norwegian Kindergartens Contemporary Issues in Early Childhood Vol 15 No 4 2014, $p$ 308-318

Henehan, K. \& Cooke, G. (IPPR 2012) Double Dutch the case against deregulation and demand-led funding in childcare. October 2012@ IPPR 2012 Institute for Public Policy Research

Henry, M., Lingard, B., Rizvi, F.\& Taylor, T. (1999) Working with/against globalization in education. Journal of Education Policy Special Issue, 14, 1, pp. 85-97

House, R. (2012) 'Why I believe the plans for EYFS reform don't make the grade', in Nursery World online article, 10 January 2012, available at: http://www.nurseryworld.co.uk/news/1111210/Why-Ibelieve-plans-EYFS- reform-dont-grade.

Hviid, P. (2011) Og ved du saa, hvor krokkodillen bor: leg og laering i mikro perspektiv, in Leg \& Laering i Fremtidens Dagtilbud, Copenehagen, BUPK. http://www.bupl.dk/iwfile/BALG8HMCK5/\$file/Forskning11.pdf

Jensen, A., Brostrom, S. \& Hansen, O. (2010) Critical Perspectives on Danish Early Education and Care; between the technical and the political, Early Years, 30: 3, 243-254.

Jensen, B (2009) A Nordic approach to Early Childhood Education (ECE) and socially endangered children, European Early Childhood Education Research Journal, 17 (1), 7- 21.

Jensen, K. (2005) Professionsfagenes krise: En udfordring til laerer-, paedagog- og sygeplejerskeuddannelserne (Crisis in the teacher, pedagogue and nursing professions), Copenhagen: 
Danmarks Pædagogiske Universitetsforlag.

Juul Jensen, J. (2011) Understandings of Danish Pedagogical Practice in Cameron, C. \& Moss, P. (2011) Social Pedagogy and Working with Children. London: Jessica Kingsley.

Kampmann, J (2013); Societalisation of early childhood education and services, European Early Childhood Education Research Journal, 21(1), 1-4.

Klitmøller, J. \& Sommer D.(Red.) (2014) Laring, dannelse og udvikling. Kvalificering til fremtiden $i$ daginstitution og skole, Copenhagen, Hans Reitzels Forlag

Kommunernes Landsforening, Undervisnings Ministeriet, Social Ministeriet, Finansministeriet (2010) Sprogvurdering adf bork i treaarsalderen, inden skolestart og i bornehaveklassen, Stottemateriale > Dagtilbud og skolen. Copenhagen, KL http://www.kl.dk/Aktuelle-temaer/kvalitetsportalen/Fagligekvalitetsoplysninger-om-dagtilbud/Redskaber-pa-dagtilbudsomradet/Sprogvurdering-af-3-arigeinden-skolestart-og-i-bornehaveklassen/

Koch, A.B. (2012) Idealet om det glade afstemte barn - paedagogers blik for trivsel i bornehaven, Nordisk Barnehageforkning, 5 (2), 1-26

Kragh-Müller, G. (2014). Kvalitet i Daginstitutioner Copenhagen; Hans Reitzel

Krog Sorensen, T. (2014) Drukner vi vores børn i tests? Jyllands-Posten, Indblik http://www.jyllandsposten.dk/premium/indblik/Indland/ECE6380064/Drukner+vi+vores+børn+i+tests\%3F/

Lenz Taguchi, H. (2010) Going Beyond the Theory/Practice Divide in Early Childhood Education: Introducing an intra-active pedagogy. London and New York: Routledge.

Lloyd, E \& Hallet, E. (2010) Professionalising the Early Childhood Workforce in England: work in progress or missed opportunity? Contemporary Issues in Early Childhood, 11 (1) 75-88

Miller, L. (2008) Developing Professionalism within a Regulatory Framework in England: challenges and possibilities, European Early Childhood Research Journal, 16(2), 255-268.

Moreau, MP. (2011) 'The societal construction of 'boys' underachievement' in educational policies: a cross-national comparison', Journal of Education Policy, 26: 2, 161 - 180

Moreau, MP. (2014): Becoming a secondary school teacher in England and France: contextualising career 'choice', Compare: A Journal of Comparative and International Education, DOI: 10.1080/03057925.2013.876310

Ministry for Families (MfF) (Familie Ministeriet), (2007) Pedagogiske Laereplaner; Pedagogical Learning Plans, Copenhagen: MfF. LOV nr 501 af 06/06/2007 https://www.retsinformation.dk/Forms/R0710.aspx?id=32025\#K2

Ministry for Families and Consumer Affairs (MfFCA) Ministeriet for Familie- og Forbrugeranliggender(MfFF) Learning Lab Denmark (2005), Guldguiden: Kobenhavn, Ministeriet for Familie- og Forbrugeranliggender(MfFF)

Ministry for Children, Equality, Integration and Social Affairs (MfCEISA) (Ministeriet for Børn, Ligestilling, Integration og Sociale Forhold) (2014) Dagtilbuds loven, https://www.retsinformation.dk/forms/r0710.aspx?id=167441 
Ministery for Social Affairs (MfSA) (Socialministeriet) (2004) Lov om aendring af lov om social service. Padagogiske laereplaner for børn I dagtilbud til børn. [Act on Educational Curricula]. Copenhagen: Socialministeriet/MfSA. LBK nr 708 af 29/06/2004 https://www.retsinformation.dk/Forms/R0710.aspx?id=20116\#A2

Ministry for Social Affairs MfSA (2005) Kjær, B. \& Olesen, J. (2005) Informationshåndbog om padagogiske laereplaner i dagtilbud Learning Lab Denmark/ Ministeriet for Familie og Forbrugeranliggende/ Styrelsen for Social Service, Kobenhavn

Ministry for Social Affairs and Welfare (MfSAW), (2010) Dagtilbudsloven: Paedagogiske laereplaner ( Pedagogical Learning Plans). Copenhagen: Socialministeriet/MfSA. SKR nr 9435 af 09/06/2010 https://www.retsinformation.dk/Forms/R0710.aspx?id=133168

Momsen, M. (2012) En styrket padagoguddannelse - anbefalinger fra Følgegruppen for padagoguddannelsen Copenthagen, Styrelsen for Videregående Uddannelser og Uddannelsesstøtte for Følgegruppen for pædagoguddannelsen

Moss P (2007) Bringing politics into the nursery: early childhood education as a democratic practice European Early Childhood Education Research Journal, 15(1), 5-20

Moss, P. (2010) We Cannot Continue as We Are: the educator in a struggle for survival, Contemporary Issues in Early Childhood, 11(1), 8-19.

Moss, P. (2012) Making Democracy a fundamental value: Meaning what exactly? In Miller, L. \& Hevey, D. Policy Issues in the Early Years. London: Sage.

Moss, P. (2013) Beyond the investment narrative, Contemporary Issues in Early Childhood, 14(4), $370-72$.

Nichols. S.L. \& Berliner, D.C. (2007) Collateral Damage: How High-Stakes Testing Corrupts America's Schools. Harvard: Harvard Education Press

NIRAS, Nielsen, H. \& Thorgård, T. (2008) Slutevaluering AKF, Danmarks Evalueringsinstitut, NIRAS Konsulenterne og UdviklingsForum Ministeriet for Fami 1 i e - og Forbrugeranliggende

Nutbrown /DfE 2012 (2012) Foundations for Quality: The independent review of early education and childcare qualifications: Final Report, (June 2012), available at: https://www.gov.uk/government/uploads/system/uploads/attachment_data/file/175463/NutbrownReview.pdf (accessed on 23/10/2013)

Oberheumer, P. (2005) 'Conceptualising the early childhood pedagogue: Policy approaches and issues of professionalism', European Early Childhood Education Research Journal 2005, 13(1) 5-16

Oberheumer, P. \& Scheryer, I. (2008) 'What professional?'in Children in Europe. Aiming High: A

Professional Workforce for the Early Years, 15: 9-12.

Olesen, A.K (2014) interviewed in Digitaliseringen kan øge læringen i dagtilbud in 'Kommunernes Landsforening temaer Bornetopmodet'

http://www.kl.dk/Faglige-kvalitetsoplysninger/Digitaliseringen-kan-oge-laringen-i-dagtilbudid147885/

Organization for Economic Cooperation and Development, OECD (2006) Starting Strong 11. Early Childhood Education and Care. Paris: OECD. http://www.oecd.org/dataoecd/23/36/31672150.pdf 
Osgood, J. (2006) Deconstructing Professionalism in Early Childhood Education: resisting the regulatory gaze, Contemporary Issues in Early Childhood, 7(1), 5-14.

Pedersen, H. (2011) BUPL: Horingssvar om aendring af dagtilbudsloven (mulighed for at private leverancorer kan traekke overskud ud af driften af udliciterede dagtilbud)

Pedersen, O. K. (2011a): Konkurrencestaten, Copenhagen, Hans Reitzels Forlag

Penn, H. (1995) Changing expectations?: A brief account of childhood services in Denmark and Spain. International Journal of Educational Management, 9(3), 26-28.

Penn, H. (2011) Quality in Early Education and Care; An International Perspective. Maindenhead. Open University Press/McGraw Hill.

Petrie, P., Boddy, J., Cameron, C., Heptinstall, E., McQuail, S., Simon, A. \& Wigfall, V. (2009) Pedagogy - a holistic, personal approach to work with children and young people, across services: European models for practice, training, education and qualification. London: Institute of Education

Pirard, F. (2012) Accompaniment and quality in childcare services: The emergence of a culture of professionalization. Early Years: An International Journal of Research and Development, 32(2), 171182.

Pramling Samuelsson for the Organization for Economic Cooperation and Development, OECD (2004): Starting Strong. Curricula and Pedagogies in Early Childhood Education and Care. Five Curriculum Outlines. Paris: OECD.

Pramling Samuelsson, I. \& Sheridan, S. ; Williams, P. (2006) Five preschool curricula - comparative perspective. International Journal of Early Childhood, 38(1), 11-29.

Professional Association for Childcare and Early Years (PACEY) (2013) Concern over 'schoolification' (Accessed July 2013)

http://www.pacey.org.uk/news/news/july_2013_news/concern_over_schoolification.aspx

Ringsmose, C. \& Kragh-Müller, G. (2013) How positive childhood experiences promote children's development of democratic skills : a reflection from Denmark. Childhood Education, Vol. 89, Nr. 4, 2013, s. 224-233).

Rose, J. and Rogers, S. (2012) 'Principles under Pressure: student teachers' perspectives on final teaching practice in early childhood classrooms', International Journal of Early Years Education, 20(1), 43-58.

Sahlberg, P. (2012) Finnish Lesson - what can the world learn from educational changes in Finland? Columbia University ,Teachers College Press Columbia University.

Servicestyrelsen (2012) Sprogvurdering - Risikofaktorer, Typer af sprogvurdering, Socialministeriets sprogvurderingsmateriale http://www.sprogpakken.dk/materialer/Sprogvurdering\%20-\%20tekst.pdf

Simpson, D. (2010) Becoming professional? Exploring Early Years Professional Status and its implications for workforce reform in England, Journal of Early Childhood Research, 8(3), 269-281.

Socialudvalget (2004) Betcenkning afgivet af Socialudvalget den 11. marts 2004 Betcenkning over Forslag til lov om aendring af lov om social service. Copenhagen, Socialudvalget (elect committee on social affairs). 
Solar, J. \& Miller, L. (2003) The Struggle for Early Childhood Curriculua: a comparison of the English Foundation Stage Curriclum, Te Whariki and Reggio Emilia. International Journal of Early Years Education. 11 (1), 57-67.

Sylva, K., and G. Pugh. (2005) Transforming the early years in England. Oxford Review of Education 31 (1): 11-27.

Tickell, C. (2011) Tickell Review of the Early Years Foundation Stage, London: DfE/DfH

Rothuizen, J. J. \& Togsverd, L. (red. 2013): Hvordan uddannes paedagoger?: Perspektiver fra et forskningsprojekt 1 udg. Århus: VIA UC Videncenter for Socialpædagogik og Socialt Arbejde. 305 s.

Tonsberg (2014) Borns leg er livsvigtig. UCC Professionshojskolen, Aktuelt https://ucc.dk/aktuelt/nyheder/boerns-leg-er-livsvigtig

Tuft (2012) Pedagog - historien om uddannelsen. Leksikon for det 21. aarhundrede: www.leksikon.org.

Tymms, P, C. Merrell, D. Hawker \& F. Nicholson/Department for Education (2014) Performance Indicators in Primary Schools: A comparison of performance on entry to school and the progress made in the first year in England and four other jurisdictions. Department for Education, London

United Nations (1989) United Nations Convention on the Rights of the Child (UNCRC), Geneva: United Nations.

United Nations Educational, Scientific and Cultural Organization (UNESCO 2010) Caring and Learning Together. Paris: UNESCO

Urban, M. (2012) Researching Early Childhood Policy and Practice. A critical ecology. European Journal of Education. 47(4) 494-507

Winter-Lindquist, D. A. (2013) Early Childhood Education in Denmark, Oxford Bibliographies http://www.oxfordbibliographies.com/view/document/obo-9780199756810/obo-97801997568100093.xml LAST MODIFIED: 07/24/2013

Ärlemalam-Hagser, E. \& Davis, J. (2014) Examining the Rhetoric: a comparison of how sustainability and young children's participation and agency are framed in Australian and Swedish early childhood education curricula Contemporary Issues in Early Childhood vol 15, nr 32014

\footnotetext{
${ }^{\mathrm{i}}$ Alongside the language assessment the 2007, the law introduced that; cooperation with parents, day-care facilities shall ensure a good transition to school by developing and supporting basic competencies and the desire to learn (MfF 2007; point 5). An example of the new discourse with emphasis on learning and planning can be seen in the extract below, where the law in 2004 stipulated that;
}

(3). Day-care facilities shall provide opportunity for experiences and activities likely to stimulate the imagination, creativity and linguistic skills of the child, and shall provide each child with space and opportunities for playing and learning, for physical exercise, for socializing and for investigating the surroundings (MoSA 2004).'

This was replaced in 2007 by 
(3). Day-care facilities shall promote children's learning and development of competencies through experiences, play and educationally (pedagogically) planned activities that give children room for contemplation, exploration and experience' (MfF 2007).

The change in the rhetoric leans towards a schoolification, stipulating the promotion of children's learning and (adult) planned activities rather than to facilitate experiences likely to stimulator the imagination. This discourse suggests a more hierarchical, adult led learning relationship, as a part of a pre-schooling focus in conjunction with language assessment of 3-year-olds (2007) and 6-year olds (2009), and the move to an earlier compulsory school start in 2011. Although not ratified in 2011, centralized learning goals were proposed, indicating a schoolification discourse that was evident as more settings moved towards testing children, with some tests assessing each child's competences and development with up to 6-700 questions (Krog Sorensen 2014). 